Research Article

\title{
Pickling Behaviour of 2205 Duplex Stainless Steel Hot-Rolled Strips in Sulfuric Acid Electrolytes
}

\author{
Jianguo Peng $\mathbb{D}^{1,2}$ and Moucheng Li $\mathbb{i D}^{1}$ \\ ${ }^{1}$ Institute of Materials, Shanghai University, Shanghai 200072, China \\ ${ }^{2}$ Research Institute, Baoshan Iron \& Steel Co., Ltd., Shanghai 200431, China \\ Correspondence should be addressed to Jianguo Peng; peng_jianguo@baosteel.com and Moucheng Li; mouchengli@shu.edu.cn
}

Received 9 August 2019; Accepted 17 March 2020; Published 9 April 2020

Academic Editor: Stefano Bellucci

Copyright (C 2020 Jianguo Peng and Moucheng Li. This is an open access article distributed under the Creative Commons Attribution License, which permits unrestricted use, distribution, and reproduction in any medium, provided the original work is properly cited.

Pickling behaviour of the oxide layer on hot-rolled 2205 duplex stainless steel (DSS) was studied in $\mathrm{H}_{2} \mathrm{SO}_{4}$ solutions with electrolytic workstation. The pickling rate at $75^{\circ} \mathrm{C}$ increases slightly with the $\mathrm{H}_{2} \mathrm{SO}_{4}$ concentration from 100 to $250 \mathrm{~g} \mathrm{~L}^{-1}$ but increases markedly as the concentration is higher than $250 \mathrm{~g} \mathrm{~L}^{-1}$. The solution temperature greatly accelerates the pickling rate. $\mathrm{Fe}^{3+}$ ion is an effective oxidant, which shows stronger inhibitive effect. The rotating disk electrode was used to simulate the moving state of steel strips in practice. The movement with the speed from 0 to $20 \mathrm{~m} \mathrm{~min}^{-1}$ results in weak acceleration effect on the pickling process. Under dynamic conditions, the pickling rate increases noticeably with changing the pulse current density from 0 to $0.2 \mathrm{~A} \mathrm{~cm}^{-2}$. The industrial pickling efficiency of $2205 \mathrm{DSS}$ hot-rolled strips increases from $5-8 \mathrm{~m} / \mathrm{min}$ to $15-18 \mathrm{~m} / \mathrm{min}$. The surface quality is improved.

\section{Introduction}

Type 2205 duplex stainless steel (DSS) has been used widely in many industries for its excellent mechanical properties and corrosion resistance [1-6]. However, the oxide scales formed on the surface of 2205 DSS during rolling and heat treatment are stable and dense due to the high chromium, molybdenum, and nitrogen contents [7]. Moreover, oxide nodules may often grow on the surface of 2205 DSS for the different oxidation rates of ferritic and austenitic phases at high temperature $[8,9]$. Therefore, the pickling of 2205 DSS hot-rolled strips is more difficult than that of standard austenitic grades [10].

The pickling process of stainless steels is used to remove the oxide scales and chromium depleted layer in order to restore the corrosion resistance and ensure the surface finish $[11,12]$. The industrial pickling process includes mechanical descaling, prepickling, and mixed acid pickling. A mechanical descaling is achieved through breaking, grinding, roto blasting, and sand blasting processes. Prepickling is performed either anodically or cathodically in acid or neutral electrolytes with certain current densities [13-15]. The general electrolytes are $\mathrm{Na}_{2} \mathrm{SO}_{4}, \mathrm{H}_{2} \mathrm{SO}_{4}, \mathrm{H}_{3} \mathrm{PO}_{4}, \mathrm{HCl}$, $\mathrm{HF}$, and $\mathrm{H}_{2} \mathrm{O}_{2}$. Mixed acid pickling is the final step to dissolve the oxide scales in $\mathrm{H}_{2} \mathrm{SO}_{4}$ - $\mathrm{HF}$ [16], $\mathrm{H}_{3} \mathrm{PO}_{4}-\mathrm{H}_{2} \mathrm{SO}_{4}$ [17], $\mathrm{HCl}-\mathrm{HF}$ [18], or $\mathrm{HNO}_{3}$-HF [19].

Prepickling plays a critical role in the industrial production process of 2205 DSS hot-rolled strips. $\mathrm{Na}_{2} \mathrm{SO}_{4}$ electrolytes can conduct electricity, but they cannot dissolve the oxides and matrix [20]. $\mathrm{H}_{2} \mathrm{SO}_{4}$ solutions can dissolve the oxide scales and matrix $[16,21] . \mathrm{H}_{3} \mathrm{PO}_{4}$ solutions have good properties of dissolving oxide scales, but their costs are expensive [22]. $\mathrm{HCl}$ solutions can dissolve ferrous oxides, but chloride corrosion is the big problem [18, 23-25]. HF solutions can dissolve oxide scales and $\mathrm{SiO}_{2}$, but there is a serious intergranular corrosion problem $[16,18]$. The dissolving effect of $\mathrm{H}_{2} \mathrm{O}_{2}$ is remarkable on the $\mathrm{Cr}$-depleted layer of stainless steel but unsatisfactory on the oxide scale $[26,27]$. After comparison, $\mathrm{H}_{2} \mathrm{SO}_{4}$ solutions are extensively used in practice for their low cost and chemical stability.

Pickling process can be simulated with static and dynamic conditions at the laboratories. There are many studies 
on static pickling [16-26], but very few on dynamic pickling [22]. The stainless steel strips in the industrial pickling process are moving. Therefore, the studies focused on dynamic pickling are of practical significance.

The pickling technology and mechanism are well known for the austenitic and ferritic stainless steels in the literature, but there are few systematical reports focused on the pickling for duplex stainless steel, especially for DSS 2205 hot-rolled strips. With the rapid development of economy and living standard, the demand for 2205 DSS is increasing quickly. However, the production of 2205 DSS is restricted greatly by its pickling process. It is necessary to study the pickling laws and improve the pickling efficiency for 2205 DSS hot-rolled strips. In this work, the pickling behaviour of the 2205 DSS hot-rolled strip in $\mathrm{H}_{2} \mathrm{SO}_{4}$ electrolytes under both static and dynamic conditions was investigated. The pickling mechanism was discussed on the basis of mass loss and surface analysis.

\section{Experimental}

2.1. Materials. A hot-rolled 2205 duplex stainless steel strip with a thickness of $4.0 \mathrm{~mm}$ was used as the test materials. Its chemical composition is given in Table 1 .

2.2. Sample Preparation. A plate of $300 \times 300 \mathrm{~mm}$ was cut from the strip and annealed at $1140^{\circ} \mathrm{C}$ for $4 \mathrm{~min}$. After annealing, the plate was taken out from the furnace and cooled down in air. The annealed plate was subjected to sand blasting to remove its main oxides on the surface and then was cut into the test specimen of $5 \times 5 \mathrm{~mm}$. The specimens were covered with epoxy resin leaving a working area of $5 \times 5 \mathrm{~mm}$ and cleaned with alcohol before pickling.

2.3. Pickling Measurement. Pickling tests were carried out on the workstation as shown in Figure 1. A specimen fixed on the rotating disk with a diameter of $15 \mathrm{~cm}$ was used as the working electrode, a platinum sheet as the counterelectrode, and $\mathrm{Hg} / \mathrm{Hg}_{2} \mathrm{SO}_{4}$ as the reference electrode. The analytically pure $\mathrm{H}_{2} \mathrm{SO}_{4}$, ferrous sulfate, iron sulfate, and deionized water were used to prepare the electrolytes. The pickling processes were performed with a Princeton potentiostat (PAR 273A).

2.4. Electrochemical Measurement. The corrosion potential and electrochemical impedance spectroscopy (EIS) of the test specimens were measured during the pickling process with a Princeton potentiostat (VMP3). Each specimen was fixed on the cell sidewall with a $1 \mathrm{~cm}^{2}$ round hole. The test specimen was used as the working electrode; the platinum sheet was used as the counterelectrode; and the $\mathrm{Hg} / \mathrm{Hg}_{2} \mathrm{SO}_{4}$ was used as the reference electrode (MSE).

All test samples were immersed in the electrolytes for 2 min. During electrolysis, the electrolytic time was 81 seconds with three periods. For each period, the specimen was polarized anodically for 18 seconds and cathodically for 9 seconds at various current densities. The pickling rate was
TABle 1: Chemical composition of 2205 DSS specimens (wt. \%).

\begin{tabular}{lcccccccc}
\hline $\mathrm{C}$ & $\mathrm{Si}$ & $\mathrm{Mn}$ & $\mathrm{S}$ & $\mathrm{P}$ & $\mathrm{Cr}$ & $\mathrm{Ni}$ & $\mathrm{Mo}$ & $\mathrm{N}$ \\
\hline 0.024 & 0.62 & 1.42 & 0.001 & 0.024 & 21.13 & 5.46 & 3.11 & 0.15 \\
\hline
\end{tabular}

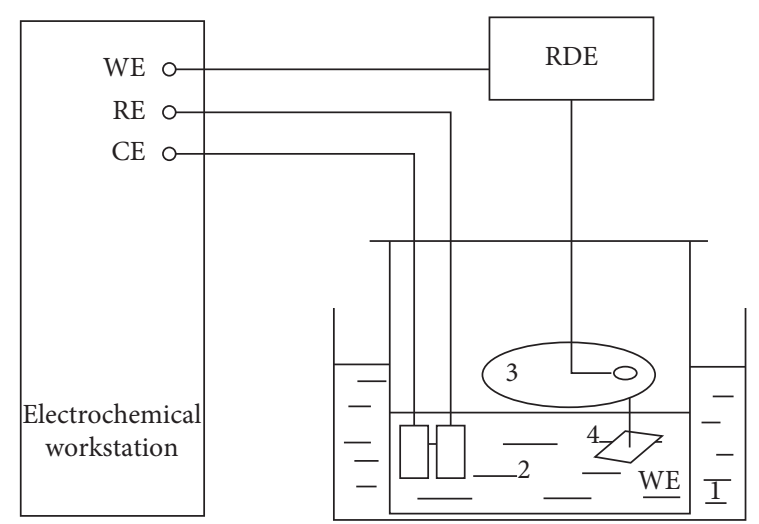

FIGURE 1: Electrolytic workstation used for dynamic pickling tests. 1, thermostat water bath; 2, electrolyte; 3, rotating disk; 4, specimen.

calculated from the mass loss of the specimen with a precision of $0.01 \mathrm{mg}$. The specimens were characterized with scanning electron microscopy (FEI Quanta 600) and Raman spectroscopy (Renishaw, inVia).

\section{Results}

3.1. Characterization of Oxide Scales. In general, the oxide scale of the hot-rolled 2205 DSS strip after annealing can be divided into an inner layer and an outer layer [7]. Chromium is rich in the inner layer while iron is rich in the outer layer. The outer layer is consisted of $\mathrm{Fe}_{2} \mathrm{O}_{3}, \mathrm{Fe}_{3} \mathrm{O}_{4}$, and $\mathrm{FeCr}_{2} \mathrm{O}_{4}$, and the inner layer is composed mainly of $\mathrm{FeCr}_{2} \mathrm{O}_{4}$ [28]. The outer layer may be partially removed by mechanical descaling. The $\mathrm{FeCr}_{2} \mathrm{O}_{4}$ is the oxide with a spinel structure, which is insoluble in most industrial acids [7, 29].

As shown in Figure 2, a few oxide scales remain on the surface of the test specimen after shot blasting. Raman spectrum in Figure 3 indicates that the residual oxides on the surface of 2205 DSS hot-rolled strip are composed of $\mathrm{Fe}_{2} \mathrm{O}_{3}$, $\mathrm{Fe}_{3} \mathrm{O}_{4}$, and $\mathrm{FeCr}_{2} \mathrm{O}_{4}$. Among them, the content of $\mathrm{FeCr}_{2} \mathrm{O}_{4}$ is the highest as seen from its peak intensity. This implies that the pickling of the 2205 DSS hot-rolled strip is difficult.

\subsection{Chemical Pickling Properties under Static Conditions.} The static chemical pickling of stainless steel in $\mathrm{H}_{2} \mathrm{SO}_{4}$ solutions is mainly related with acid concentration, pickling temperature, and concentration of metal ions. For most steels, higher pickling temperature, higher concentration of $\mathrm{H}_{2} \mathrm{SO}_{4}$ solutions, and lower concentration of metal ions can improve its pickling efficiency in the initial pickling stage for its strong dissolving capacity. After pickling for a certain time, the strong dissolving capacity may deteriorate pickling result for the corrosion of matrix. 


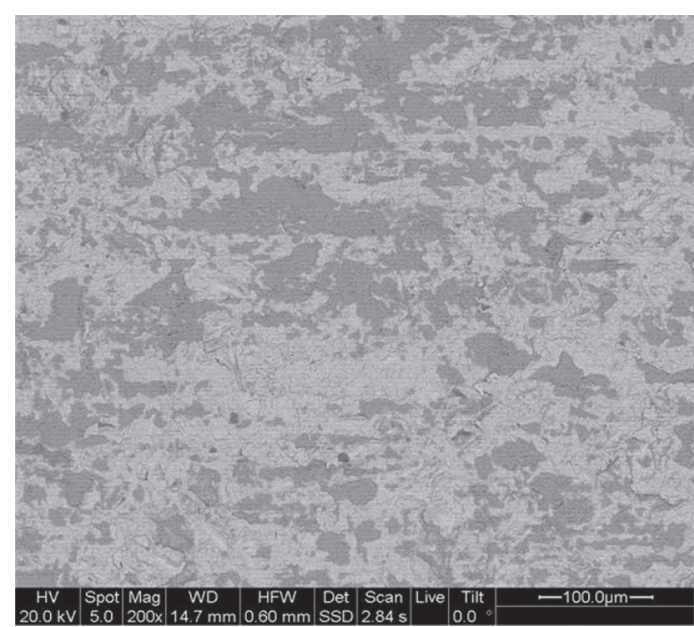

FIGURE 2: Surface image for the test specimen.

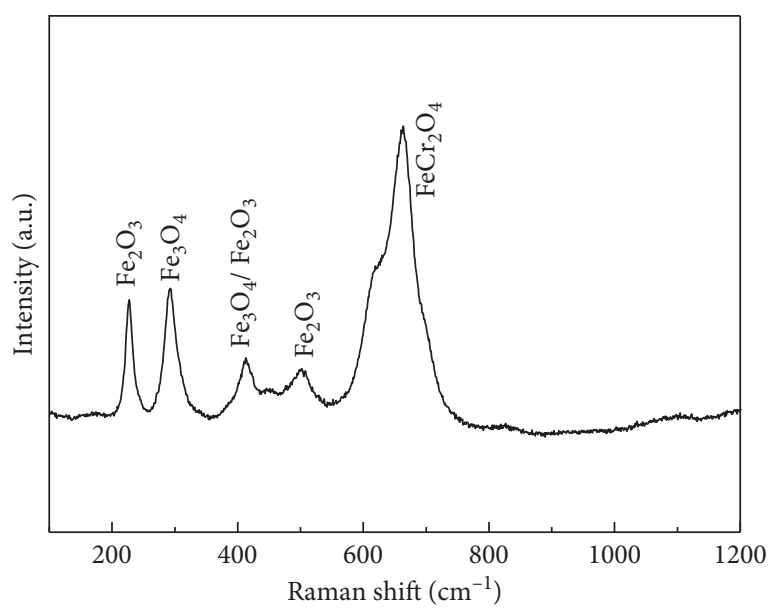

FIgURE 3: Raman spectrum for the test specimen.

The effect of $\mathrm{H}_{2} \mathrm{SO}_{4}$ concentration on static pickling rate and typical surface images of specimens at $75^{\circ} \mathrm{C}$ are shown in Figures 4 and 5 . The pickling efficiency has a positive correlation with $\mathrm{H}_{2} \mathrm{SO}_{4}$ concentration. It can be seen that the pickling rate has a transition at about $250 \mathrm{~g} \mathrm{~L}^{-1}$. When the concentration increases from $100 \mathrm{gL}^{-1}$ to $250 \mathrm{~g} \mathrm{~L}^{-1}$, the pickling rate is accelerated slightly and many oxide scales remain on the surface. When the concentration increases from $250 \mathrm{~g} \mathrm{~L}^{-1}$ to $450 \mathrm{~g} \mathrm{~L}^{-1}$, the pickling rate is accelerated markedly to remove most of the oxide scales.

Figure 6 gives the static pickling rates of specimens in $300 \mathrm{~g} \mathrm{~L}^{-1} \mathrm{H}_{2} \mathrm{SO}_{4}$ solutions at different temperatures. The pickling efficiency has a positive correlation with the solution temperature. With the increasing temperature from $50^{\circ} \mathrm{C}$ to $90^{\circ} \mathrm{C}$, the pickling rate increases gradually from about 1.74 to $12.8 \mathrm{~g} \mathrm{~m}^{-2} \mathrm{~min}^{-1}$ and the retained oxide scales reduced noticeably, as shown in Figure 7.

The metal ions in the $\mathrm{H}_{2} \mathrm{SO}_{4}$ solutions include iron, chromium, molybdenum, nickel, manganese, titanium, and niobium ions. The conventional metal elements in industrial $\mathrm{H}_{2} \mathrm{SO}_{4}$ electrolytes are shown in Table 2. Among them, iron is the main element. Therefore, the iron ions play the main impact on the pickling process.

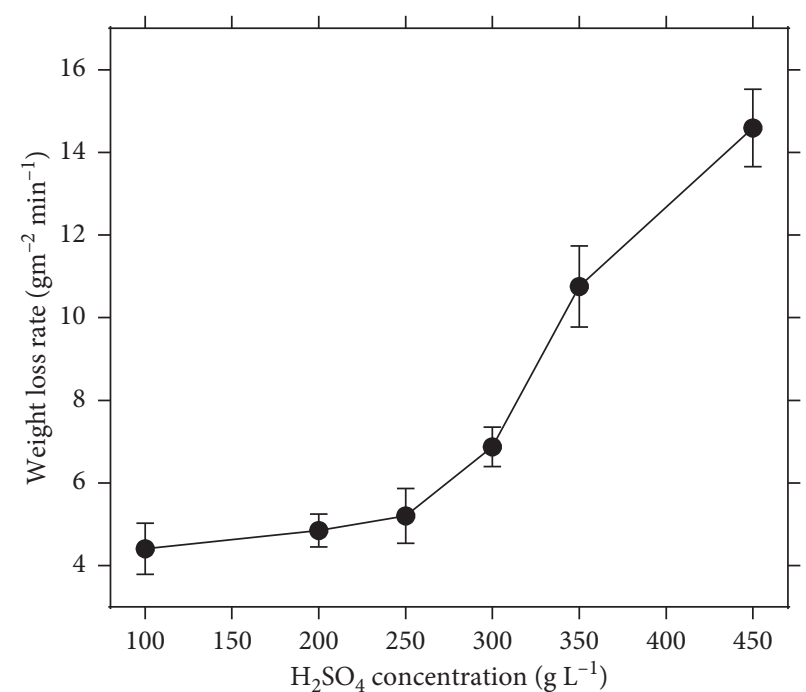

FIGURE 4: Variation of the static pickling rate in $\mathrm{H}_{2} \mathrm{SO}_{4}$ at $75^{\circ} \mathrm{C}$ with different concentrations.

The effect of iron ions on the static pickling of the specimen was studied in $300 \mathrm{~g} \mathrm{~L}^{-1} \mathrm{H}_{2} \mathrm{SO}_{4}$ solutions at $75^{\circ} \mathrm{C}$ and the results are given in Figure 8. The pickling efficiency has a negative correlation with the concentration of iron ions. With increasing concentration of ferric ions from $0.5 \mathrm{~g} \mathrm{~L}^{-1}$ to $60 \mathrm{~g} \mathrm{~L}^{-1}$, the pickling rate declines sharply at first to less than $1 \mathrm{~g} \mathrm{~m}^{-2} \mathrm{~min}^{-1}$ and then decreases insignificantly. With increasing concentration of ferrous ions, the pickling rate decreases slowly, but shows higher values in comparison with ferric ions. The ferric ions are an effective oxidant which can enhance the corrosion potential of test specimens [16] and then reduce their dissolution rate remarkably. In order to improve the pickling rate of 2205 DSS hot-rolled strips, new sulfuric acid solutions without iron ions are necessary.

3.3. Chemical Pickling Properties under Dynamic Conditions. In order to see the difference between dynamic and static pickling of hot-rolled 2205 DSS strips, the rotating disk was applied to create the movement between specimens and acid solutions. The variation of pickling rate of the specimen in $300 \mathrm{~g} \mathrm{~L}^{-1} \mathrm{H}_{2} \mathrm{SO}_{4}$ solutions at $75^{\circ} \mathrm{C}$ with rotary speed is given in Figure 9. The pickling efficiency has a positive correlation with moving speed of the specimen. The pickling rate is higher in the dynamic cases than in the static case. However, with the increase of rotary speed from 5 to $20 \mathrm{~m} \mathrm{~min}^{-1}$, the pickling rate only enlarges slightly from about 7.5 to $7.8 \mathrm{~g} \mathrm{~m}^{-2} \mathrm{~min}^{-1}$. It is evident that the acceleration effect of dynamic speed is very weak.

3.4. Electrolytic Pickling Properties under Dynamic Conditions. The applied polarization plays a role in pickling process. Figure 10 gives the variation of the dynamic pickling rate at $10 \mathrm{~m} \mathrm{~min}^{-1}$ for specimens in $300 \mathrm{~g} \mathrm{~L}^{-1} \mathrm{H}_{2} \mathrm{SO}_{4}$ solutions at $75^{\circ} \mathrm{C}$ with pulse current density. The pickling rate becomes higher with increasing the pulse current density from 0 to $0.2^{\circ} \mathrm{A} \mathrm{cm}^{-2}$. The rate is about 2.1 times larger at 


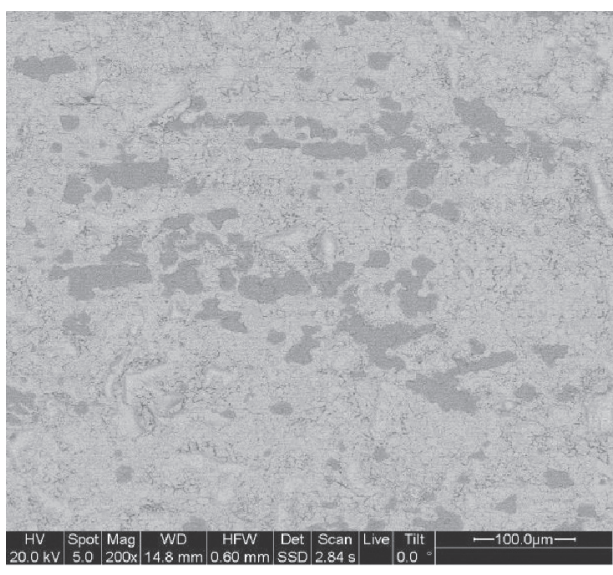

(a)

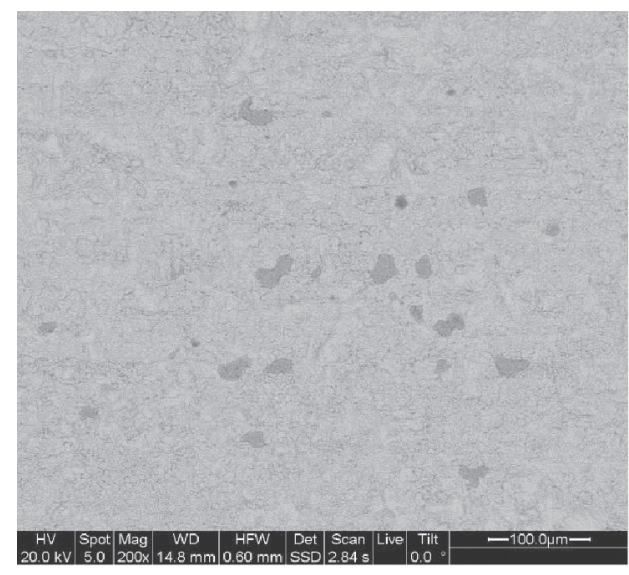

(b)

Figure 5: SEM surface images after static pickling in $\mathrm{H}_{2} \mathrm{SO}_{4}$ solutions at $75^{\circ} \mathrm{C}$ with different concentrations: (a) $300 \mathrm{gL}^{-1}$ and (b) $450 \mathrm{~g} \mathrm{~L}$.

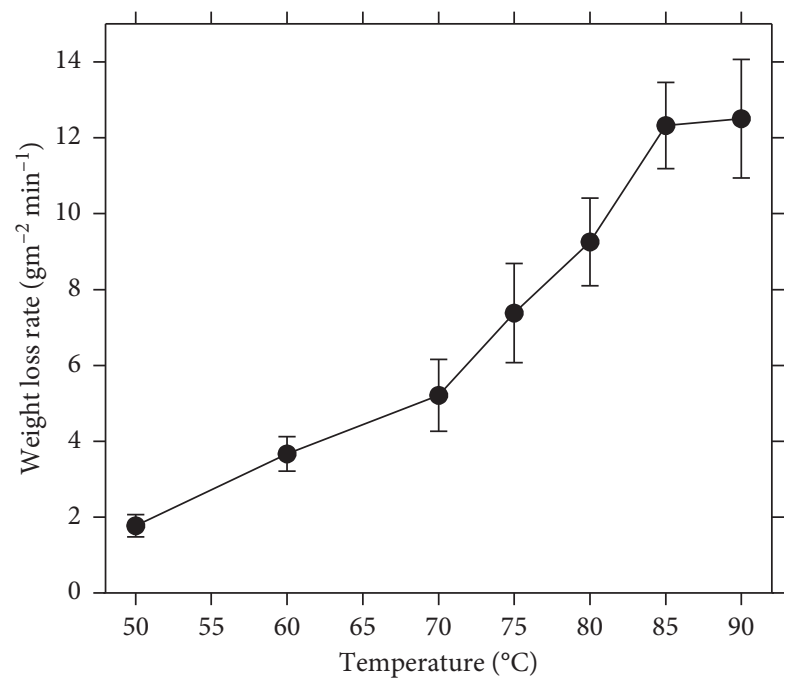

FIGURE 6: The static pickling rate of the specimen in $300 \mathrm{~g} \mathrm{~L}^{-1} \mathrm{H}_{2} \mathrm{SO}_{4}$ solutions at different temperatures.

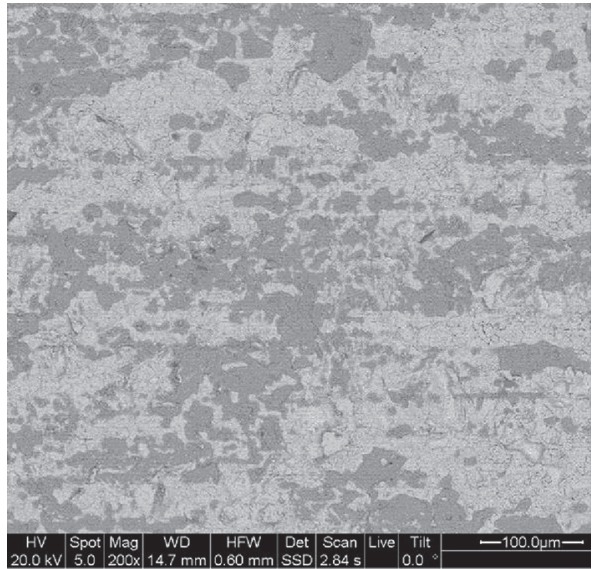

(a)

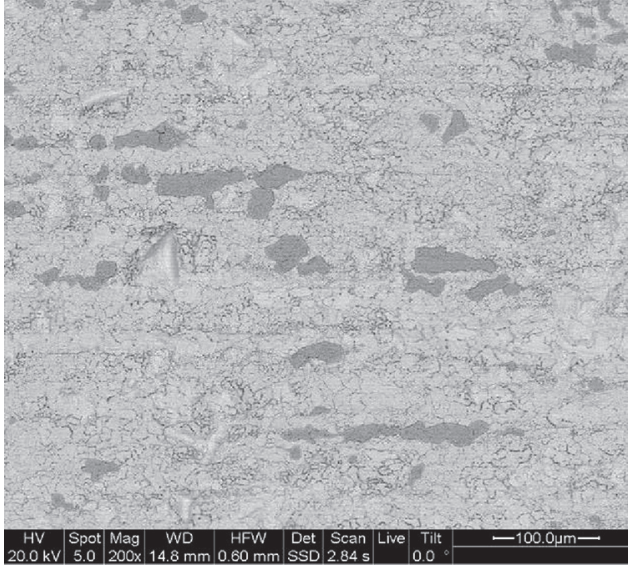

(b)

FIGURE 7: SEM surface images after static pickling in $300 \mathrm{~g} \mathrm{~L}^{-1} \mathrm{H}_{2} \mathrm{SO}_{4}$ solutions at temperatures $60^{\circ} \mathrm{C}$ (a) and $90^{\circ} \mathrm{C}(\mathrm{b})$. 
TABLE 2: Concentration of metal ions in industrial $\mathrm{H}_{2} \mathrm{SO}_{4}$ solutions.

\begin{tabular}{lcccccccc}
\hline Ions & $\mathrm{Fe}$ & $\mathrm{Cr}$ & $\mathrm{Mn}$ & $\mathrm{Ni}$ & $\mathrm{Cu}$ & $\mathrm{Nb}$ & $\mathrm{Ti}$ & $\mathrm{Mo}$ \\
\hline $\begin{array}{l}\text { Concentration } \\
(\mathrm{g} / \mathrm{L})\end{array}$ & 20.6 & 2.80 & 0.06 & 0.55 & $<0.01$ & $<0.01$ & $<0.01$ & 0.04 \\
\hline
\end{tabular}

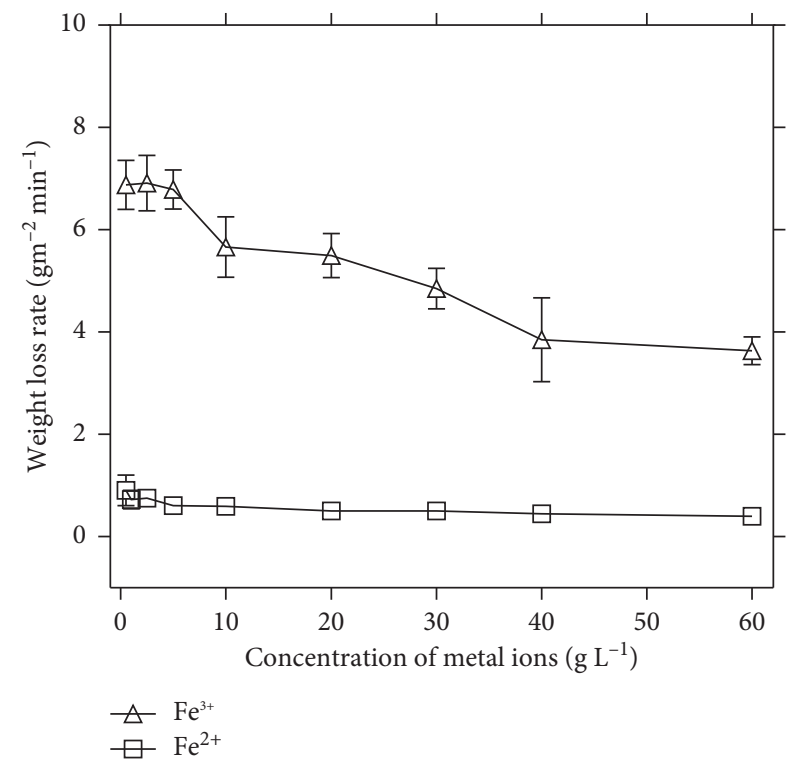

FIGURE 8: The static pickling rate in $300 \mathrm{~g} \mathrm{~L}^{-1} \mathrm{H}_{2} \mathrm{SO}_{4}$ solutions at $75^{\circ} \mathrm{C}$ with different iron ions.

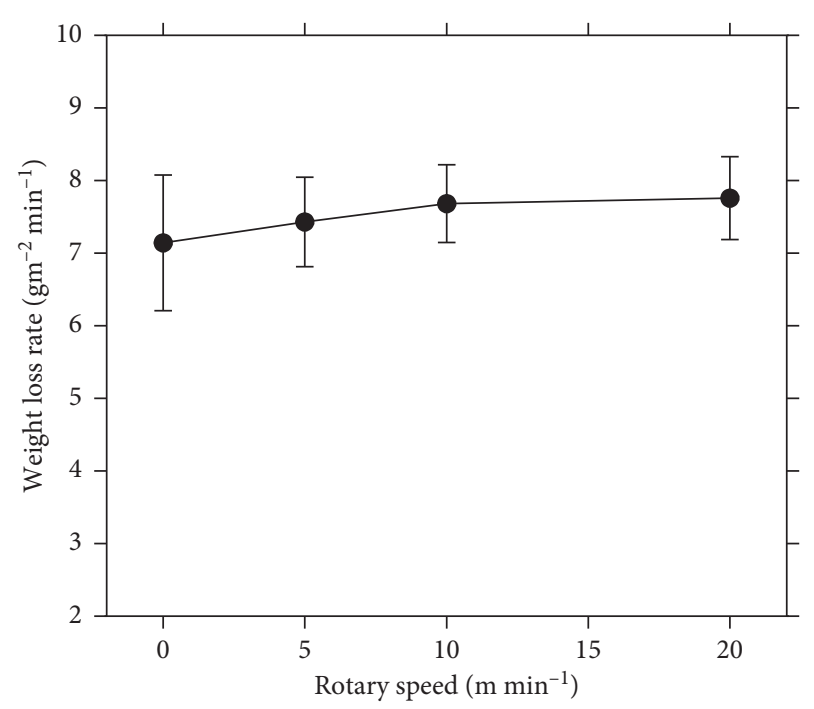

Figure 9: Dynamic pickling rate in $300 \mathrm{~g} \mathrm{~L}^{-1} \mathrm{H}_{2} \mathrm{SO}_{4}$ solutions at $75^{\circ} \mathrm{C}$ under different rotary speed conditions.

$0.2 \mathrm{~A} \mathrm{~cm}^{-2}$ than at $0 \mathrm{~A} \mathrm{~cm}^{-2}$ (i.e., the chemical pickling). The electrolytic pickling efficiency has a positive correlation with the pulse current density. After dynamic electrolytic pickling, there is almost no oxide scales on the specimen surfaces compared with static electrolytic pickling. With the increase of current density from $0.04 \mathrm{~A} \mathrm{~cm}^{-2}$ to $0.2 \mathrm{~A} \mathrm{~cm}^{-2}$, the $\mathrm{Cr}$ depleted layer may dissolve obviously and the surfaces become smooth, as shown in Figure 11.

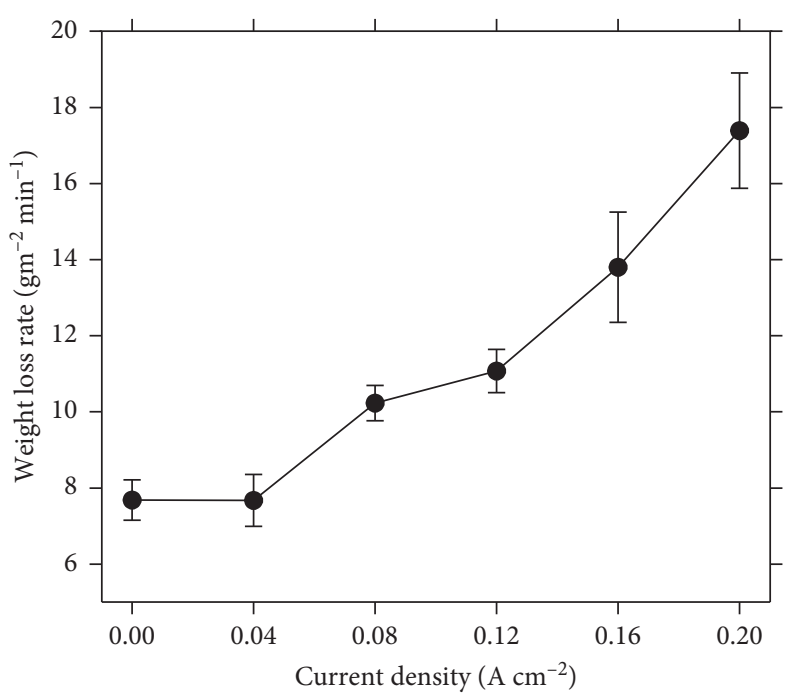

FIgURE 10: Variation of the dynamic pickling rate with current density in $300 \mathrm{~g} \mathrm{~L}^{-1} \mathrm{H}_{2} \mathrm{SO}_{4}$ solutions at $75^{\circ} \mathrm{C}$.

\section{Discussion}

The residual oxides on the surface of the test specimen are composed of $\mathrm{Fe}_{2} \mathrm{O}_{3}, \mathrm{Fe}_{3} \mathrm{O}_{4}$, and $\mathrm{FeCr}_{2} \mathrm{O}_{4}$, as shown in Figure 3. While pickling of 2205 DSS hot-rolled strips in $\mathrm{H}_{2} \mathrm{SO}_{4}$ electrolytes, it involves two processes, chemical pickling process and electrolytic pickling process.

When chemical pickling is carried on for $2205 \mathrm{DSS}, \mathrm{FeO}$, $\mathrm{Fe}_{2} \mathrm{O}_{3}, \mathrm{Fe}_{3} \mathrm{O}_{4}$, and alloying elements can be dissolved in $\mathrm{H}_{2} \mathrm{SO}_{4}$ solutions. The chemical pickling process involves the following chemical reactions [30]:

$$
\begin{gathered}
\mathrm{FeO}+\mathrm{H}_{2} \mathrm{SO}_{4} \longrightarrow \mathrm{FeSO}_{4}+\mathrm{H}_{2} \mathrm{O} \\
\mathrm{Fe}_{3} \mathrm{O}_{4}+4 \mathrm{H}_{2} \mathrm{SO}_{4} \longrightarrow \mathrm{FeSO}_{4}+\mathrm{Fe}_{2}\left(\mathrm{SO}_{4}\right)_{3}+4 \mathrm{H}_{2} \mathrm{O} \\
\mathrm{Fe}_{2} \mathrm{O}_{3}+3 \mathrm{H}_{2} \mathrm{SO}_{4} \longrightarrow \mathrm{Fe}_{2}\left(\mathrm{SO}_{4}\right)_{3}+3 \mathrm{H}_{2} \mathrm{O} \\
\mathrm{Fe}+\mathrm{H}_{2} \mathrm{SO}_{4} \longrightarrow \mathrm{FeSO}_{4}+\mathrm{H}_{2} \uparrow \\
\mathrm{Ni}+\mathrm{H}_{2} \mathrm{SO}_{4} \longrightarrow \mathrm{NiSO}_{4}+\mathrm{H}_{2} \uparrow \\
\mathrm{Cr}+\mathrm{H}_{2} \mathrm{SO}_{4} \longrightarrow \mathrm{CrSO}_{4}+\mathrm{H}_{2} \uparrow
\end{gathered}
$$

The oxide scales on the test specimen are mainly comprised of $\mathrm{FeCr}_{2} \mathrm{O}_{4}$, as shown in Figure 3. The $\mathrm{FeCr}_{2} \mathrm{O}_{4}$ is insoluble in sulfuric acid solution [7]. The matrix of 2205 DSS is dissolved slowly in sulfuric acid solution for its excellent corrosion resistance. The oxide scales on the test specimen are dissolved very slowly in sulfuric acid solutions by means of peeling mechanically. Therefore, the chemical pickling of the 2205 DSS hot-rolled strip is very slow. For most stainless steels, higher pickling temperature and sulfuric acid concentration do not increase their pickling efficiency after a certain level [30]. But, for 2205 DSS, the oxide scales still exist after chemical pickling in $450 \mathrm{~g} \mathrm{~L}^{-1} \mathrm{H}_{2} \mathrm{SO}_{4}$ at $90^{\circ} \mathrm{C}$. 


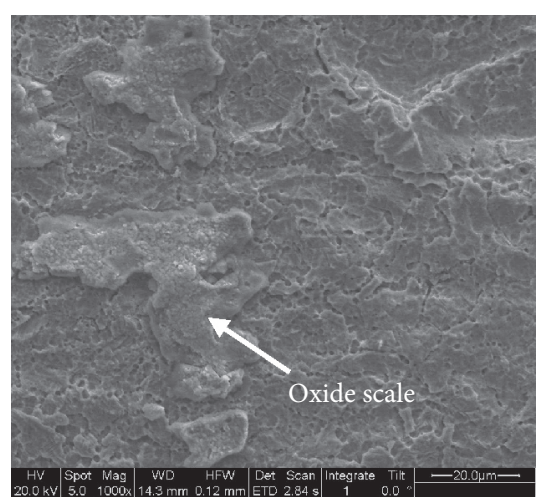

(a)

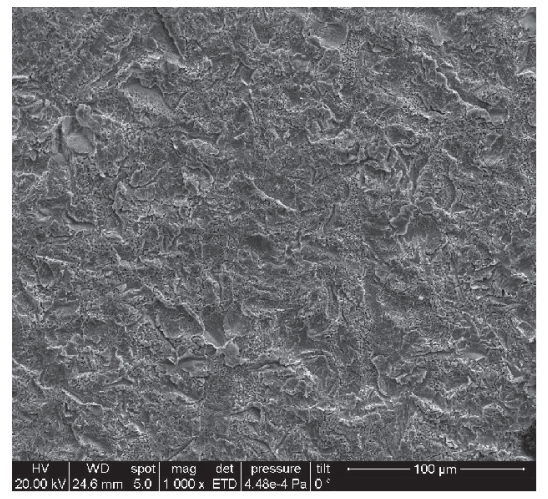

(d)

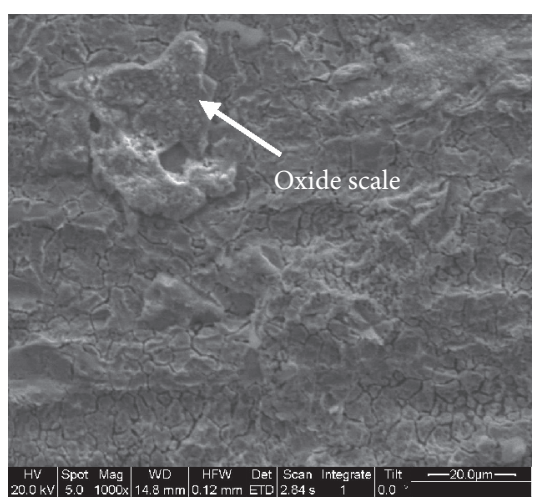

(b)

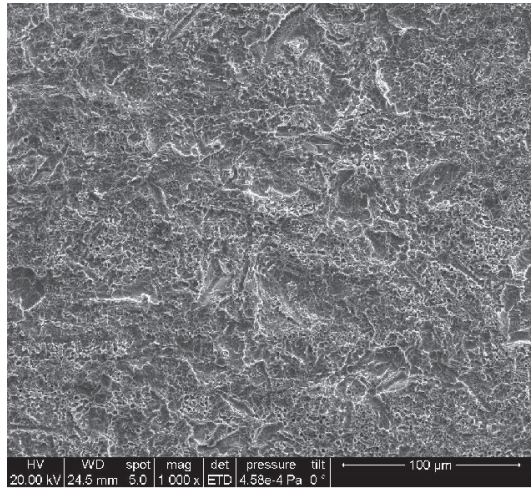

(e)

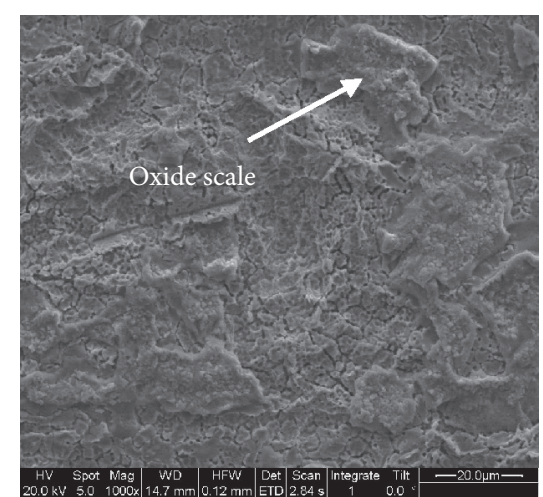

(c)

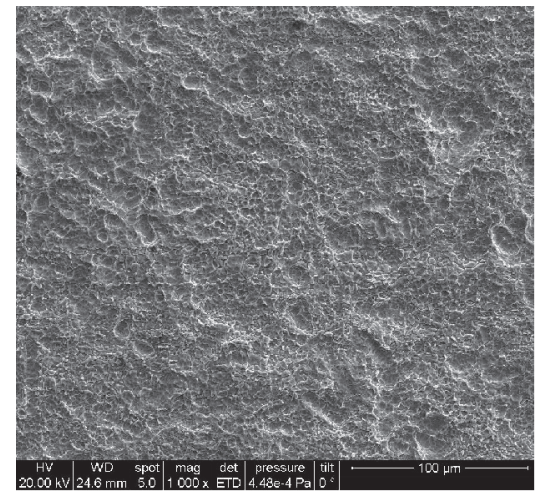

(f)

Figure 11: SEM surface images after static (a-c)) and dynamic (d-f)) pickling in $300 \mathrm{~g} \mathrm{~L}^{-1} \mathrm{H}_{2} \mathrm{SO}_{4}$ solutions at $75^{\circ} \mathrm{C}$ with current density $0.04 \mathrm{~A} \mathrm{~cm}^{-2}$ (a and d), $0.12 \mathrm{~A} \mathrm{~cm}^{-2}$ (b and $\mathrm{e}$ ), and $0.2 \mathrm{~A} \mathrm{~cm}^{-2}$ (c and f).

At the beginning of the static chemical pickling process, small gas bubbles nucleate and grow on the specimen surface. During the pickling process, more and more gas bubbles will form and adsorb on the specimen surface, which must reduce the contact areas of effective pickling. As for the dynamic pickling of specimens on the rotating disk, the movement may decrease the adsorption and growth of gas bubbles on the specimen surface to a certain extent [31]. Therefore, the chemical pickling rate of the annealed 2205 DSS specimens under dynamic condition is higher than under static condition. Nevertheless, the acceleration effect of dynamic speed is very weak, with about $5 \sim 10 \%$ increase in the pickling rates, as observed in Figure 8.

When sulfuric acid is used as an electrolyte, it can conduct electricity. The test specimen serves as the anode and cathode with the alternative change. When the test specimen serves as the relative anode, the insoluble $\mathrm{FeCr}_{2} \mathrm{O}_{4}$ is oxidized into soluble $\mathrm{HCrO}_{4}{ }^{-}$and $\mathrm{Cr}_{2} \mathrm{O}_{7}{ }^{2-}$. The anodic electrolytic reactions are as follows [10, 30, 32]:

$$
\begin{aligned}
2 \mathrm{H}_{2} \mathrm{O} & \longrightarrow \mathrm{O}_{2} \uparrow+4 \mathrm{H}^{+}+4 \mathrm{e} \\
\mathrm{FeCr}_{2} \mathrm{O}_{4}+4 \mathrm{H}_{2} \mathrm{O} & \longrightarrow \mathrm{FeO}+\mathrm{HCrO}_{4}{ }^{-}+7 \mathrm{H}^{+}+6 \mathrm{e} \\
\mathrm{FeCr}_{2} \mathrm{O}_{4}+4 \mathrm{H}_{2} \mathrm{O} & \longrightarrow \mathrm{FeO}+\mathrm{Cr}_{2} \mathrm{O}_{7}{ }^{2-}+8 \mathrm{H}^{+}+6 \mathrm{e} \\
2 \mathrm{FeO}_{3} & \longrightarrow 4 \mathrm{Fe}^{3+}+3 \mathrm{O}_{2} \uparrow+12 \mathrm{e}
\end{aligned}
$$

When the test specimen serves as the relative cathode, $\mathrm{Cr}(\mathrm{OH})_{3}$ and $\mathrm{Fe}(\mathrm{OH})_{3}$ are deposited on the surface of the test specimen. $\mathrm{H}_{2}$ is precipitated between the oxide layers, which is beneficial to the separation of the deposited sediment from the matrix. The cathodic electrolytic reactions are as follows $[10,30,32]$ :

$$
\begin{gathered}
2 \mathrm{H}_{2} \mathrm{O}+2 \mathrm{e} \longrightarrow 2 \mathrm{OH}^{-}+\mathrm{H}_{2} \uparrow \\
\mathrm{Fe}^{3+}+3 \mathrm{OH}^{-} \longrightarrow \mathrm{Fe}(\mathrm{OH})_{3} \downarrow \\
\mathrm{CrO}_{4}{ }^{2-}+4 \mathrm{H}_{2} \mathrm{O}+6 \mathrm{e} \\
\mathrm{Cr}_{2} \mathrm{O}_{7}{ }^{2-}+4 \mathrm{H}_{2} \mathrm{O}+6 \mathrm{Cr}(\mathrm{OH})_{3} \downarrow
\end{gathered}
$$

Electrolytic pickling is faster than normal chemical pickling for most stainless steels [20]. The electrolytic pickling process in $\mathrm{H}_{2} \mathrm{SO}_{4}$ electrolytes is the combined effect of electrolysis and chemical pickling. When the electrolytic pickling is performed under static conditions, a maximum of about $20 \%$ of the current goes to dissolution reactions, whereas about $80 \%$ of the current is consumed in oxygen gas production [10]. For the dense and compact oxide scales of the test specimens, spallation or peeling of the oxide scales induced by gas evolution does not play a decisive role. As shown in Figure 11, the oxide scales are remained on the test specimens after static electrolytic pickling. When the 


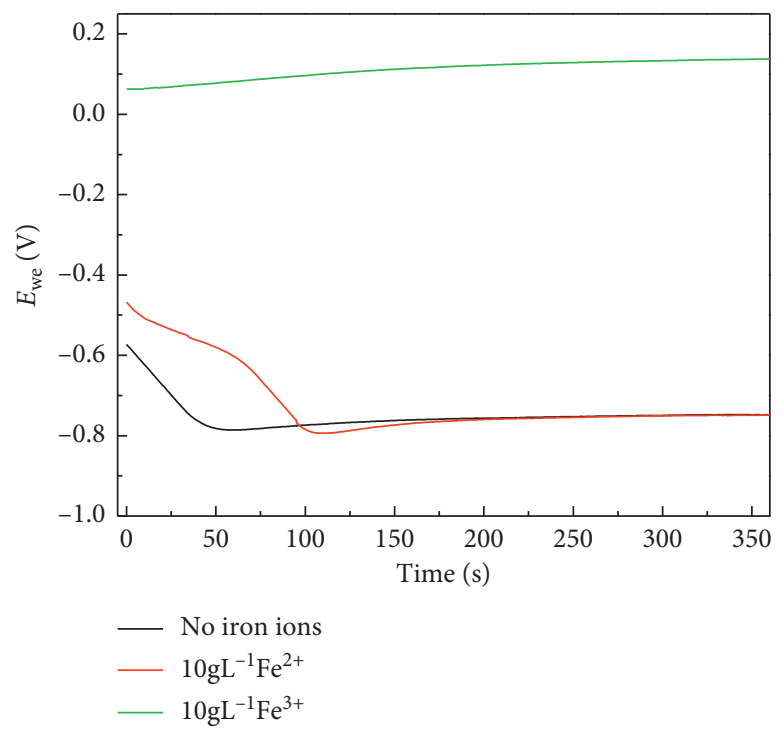

FIGURE 12: Corrosion potential in $300 \mathrm{~g} \mathrm{~L}^{-1} \mathrm{H}_{2} \mathrm{SO}_{4}$ solutions at $75^{\circ} \mathrm{C}$ containing different $\mathrm{Fe}$ ions.

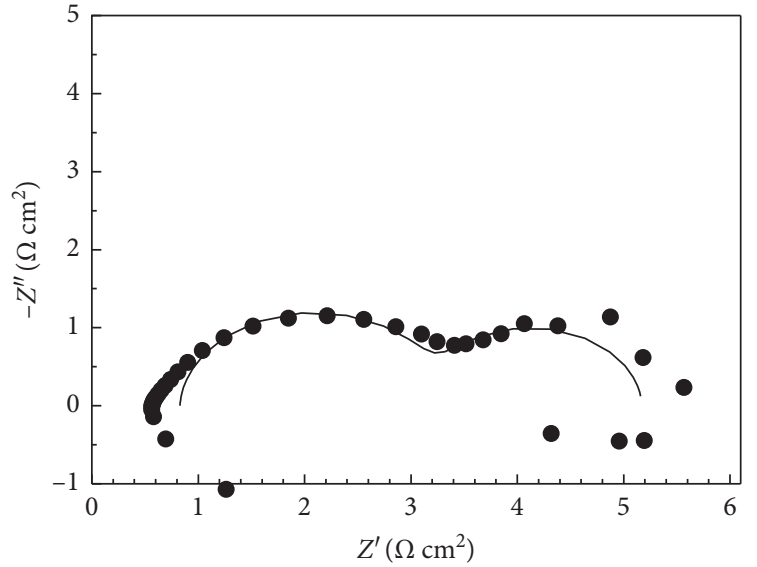

(a)

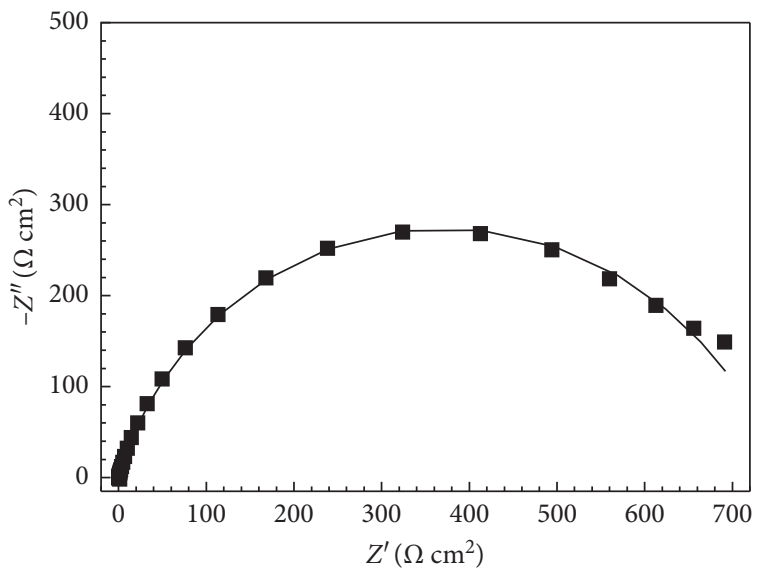

(c)

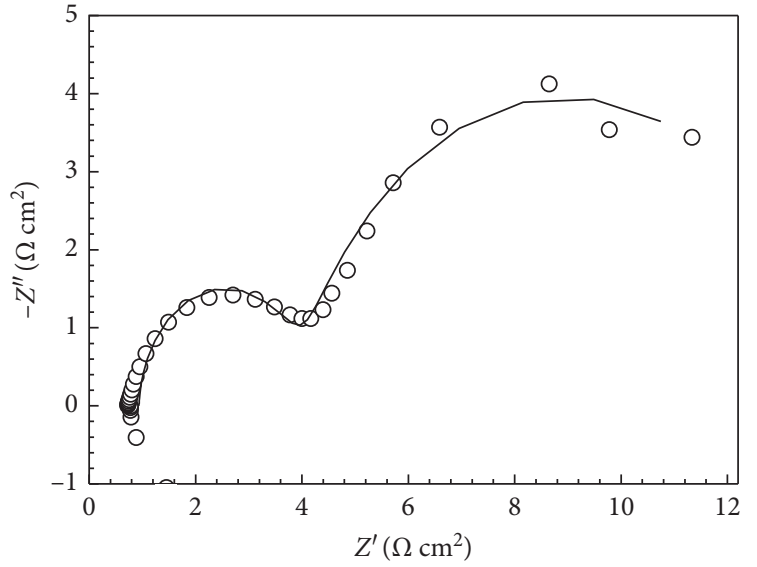

(b)

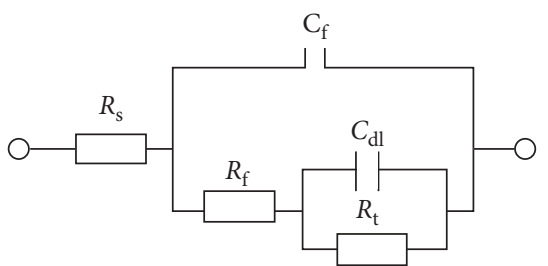

(d)

Figure 13: Nyquist plots in $300 \mathrm{~g} \mathrm{~L}^{-1} \mathrm{H}_{2} \mathrm{SO}_{4}$ solutions at $75^{\circ} \mathrm{C}$ containing no ions (a), $10 \mathrm{gL}^{-1} \mathrm{Fe}^{2+}$ (b), and $10 \mathrm{gL}^{-1} \mathrm{Fe}^{3+}$ (c), and the corresponding circuit of the impedance spectrum (d). 
TABLE 3: Fitted results for EIS spectra in $300 \mathrm{~g} \mathrm{~L}^{-1} \mathrm{H}_{2} \mathrm{SO}_{4}$ solutions at $75^{\circ} \mathrm{C}$ containing different ions.

\begin{tabular}{lccccccc}
\hline Ions & $R_{s}, \Omega \mathrm{cm}^{2}$ & $Y_{0-\mathrm{f}} S^{\alpha}, \Omega^{-1} \mathrm{~cm}^{-2}$ & $\alpha_{\mathrm{f}}$ & $R_{\mathrm{f}}, \Omega \mathrm{cm}^{2}$ & $Y_{0-\mathrm{dl}} S^{\alpha}, \Omega^{-1} \mathrm{~cm}^{-2}$ & $\alpha_{\mathrm{dl}}$ & $R_{\mathrm{t}}, \Omega \mathrm{cm}^{2}$ \\
\hline No ions & 0.82 & 0.00218 & 0.87 & 2.80 & 0.0658 & 0.92 \\
$10 \mathrm{~g} \mathrm{~L}^{-1} \mathrm{Fe}^{2+}$ & 0.94 & 0.00185 & 0.96 & 3.14 & 0.093 & 0.84 \\
$10 \mathrm{~g} \mathrm{~L}^{-1} \mathrm{Fe}^{3+}$ & 1.04 & 0.000133 & 0.95 & 54.99 & 0.000281 & 1.6 \\
\hline
\end{tabular}

electrolytic pickling is performed under dynamic conditions, the rotary disk develops a rational way for producing active edges efficiently, where catalytic activity of the test specimens is improved and its pickling rate is accelerated $[33,34]$. The dynamic electrolytic pickling rate at $0.2 \mathrm{~A} \mathrm{~cm}^{-2}$ is about 2.1 times higher than the chemical pickling, which may give rise to a smooth specimen surface without oxide scales.

The $\mathrm{Fe}^{3+}$ ions are an effective oxidant which enhanced the corrosion potential, as shown in Figure 12. When no Fe ions were added in the $\mathrm{H}_{2} \mathrm{SO}_{4}$ solutions, the corrosion potential quickly declined at the beginning of the immersion time; after about $50 \mathrm{~s}$, it remained constant (approximately $-0.75 \mathrm{~V}_{\text {MSE }}$ ) subsequently as the immersion time increased. When $10 \mathrm{~g} \mathrm{~L}^{-1} \mathrm{Fe}^{2+}$ was added in the $\mathrm{H}_{2} \mathrm{SO}_{4}$ solutions, the corrosion potential quickly declined at the beginning of the immersion time; after about $100 \mathrm{~s}$, it remained unchanged. When $10 \mathrm{~g} \mathrm{~L}^{-1} \mathrm{Fe}^{3+}$ was added in the $\mathrm{H}_{2} \mathrm{SO}_{4}$ solutions, the corrosion potential increased slowly from $0.062 \mathrm{~V}_{\mathrm{MSE}}$ to $0.137 \mathrm{~V}_{\text {MSE }}$ as the immersion time increased. The EIS Nyquist plots recorded on the test specimens immersed in $300 \mathrm{~g} \mathrm{~L}^{-1} \mathrm{H}_{2} \mathrm{SO}_{4}$ solutions containing no ions, $10 \mathrm{~g} \mathrm{~L}^{-1} \mathrm{Fe}^{2+}$, and $10 \mathrm{~g} \mathrm{~L}^{-1} \mathrm{Fe}^{3+}$ under the $\mathrm{E}_{\text {corr }}$ conditions (i.e., the free corrosion states) is presented in Figure 13. The semicircle size enlarged slightly with the addition of $10 \mathrm{~g} \mathrm{~L}^{-1} \mathrm{Fe}^{2+}$ but increased noticeably with the addition of the $10 \mathrm{~g} \mathrm{~L}^{-1} \mathrm{Fe}^{3+}$ for its high impedance.

In order to show the dissolution process for the specimens in $300 \mathrm{~g} \mathrm{~L}^{-1} \mathrm{H}_{2} \mathrm{SO}_{4}$ solutions at $75^{\circ} \mathrm{C}$ containing different $\mathrm{Fe}$ ions, the equivalent circuit model is proposed in Figure 13(d) according to the EIS features in Figure 13. $R_{\mathrm{s}}$ is the electrolyte resistance. $R_{\mathrm{f}}$ is the resistance of oxide layer remained on the specimens. $R_{\mathrm{t}}$ is the charge transfer resistance. $C_{\mathrm{f}}$ and $C_{\mathrm{dl}}$ can be replaced with constant phase element (CPE) [35]. The impedance of CPE is written in equation (15), where $Y_{0}$ is the admittance magnitude of CPE and $\alpha$ is the exponential term. Table 3 gives the fitted results of EIS spectra. The calculated spectra are shown as a solid curve in Figure 13, which fit the experimental data very well. It can be concluded that the model provided a reliable description for the corrosion systems.

$$
Z_{\mathrm{CPE}}=\frac{1}{Y_{0}(j \omega)^{\alpha}} \text {. }
$$

\section{Application and Performance}

According to the abovementioned results, the pickling process of hot-rolled 2205 DSS is optimized through the high $\mathrm{H}_{2} \mathrm{SO}_{4}$ concentration, high solution temperature, and proper electrolysis current density in the industrial prepickling of 2205 DSS hot-rolled strips. The pickling efficiency is improved remarkably, which increases the

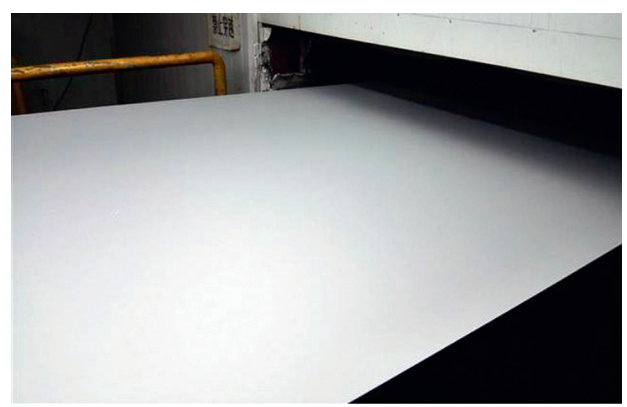

FIGURE 14: Optical surface of the 2205 DSS hot-rolled strip after industrial pickling with optimized pickling process.

production rate from $5-8 \mathrm{~m} \mathrm{~min}^{-1}$ to $15-18 \mathrm{~m} \mathrm{~min}^{-1}$. Besides, the surface finish after pickling is notably enhanced, as shown in Figure 14.

\section{Conclusion}

The pickling behaviour of hot-rolled 2205 DSS with annealing and mechanical descaling treatments in $\mathrm{H}_{2} \mathrm{SO}_{4}$ solutions under both static and dynamic conditions has led to the following conclusions:

(1) In the static chemical pickling process, the pickling rate may be accelerated noticeably by increasing the solution temperature and $\mathrm{H}_{2} \mathrm{SO}_{4}$ concentration, but be decelerated greatly by $\mathrm{Fe}^{3+}$ ions.

(2) The chemical pickling process can be enhanced weakly by the moving speed of the specimen from 0 to $20 \mathrm{~m} \mathrm{~min}^{-1}$ because the movement decreases the adsorption and growth of gas bubbles on the specimen surface to a certain extent.

(3) Under dynamic conditions, the electrolytic pickling rate increases markedly with changing the pulse current density from 0.04 to $0.2 \mathrm{~A} \mathrm{~cm}^{-2}$. The electrolytic pickling rate at $0.2 \mathrm{~A} \mathrm{~cm}^{-2}$ is about 2.1 times larger than the chemical pickling rate in $300 \mathrm{~g} \mathrm{~L}^{-1} \mathrm{H}_{2} \mathrm{SO}_{4}$ at $75^{\circ} \mathrm{C}$, resulting in the smooth and clean specimen surfaces.

\section{Data Availability}

The tables and figures data used to support the findings of this study are available from the corresponding author upon reasonable request.

\section{Conflicts of Interest}

The authors declare that there are no conflicts of interest regarding the publication of this paper. 


\section{Acknowledgments}

The authors gratefully acknowledge the financial support from the National Natural Science Foundation of China (Grant nos. U1660205 and U1960103).

\section{References}

[1] Y.-Y. Wu and F. Presuel-Moreno, "Chloride levels that initiated corrosion of duplex stainless steel embedded in mortar," Advances in Materials Science and Engineering, vol. 2019, Article ID 6949176, 6 pages, 2019.

[2] T. Li, Y. Zhang, L. Gao, and Y. Zhang, "Optimization of FCAW parameters for ferrite content in 2205 DSS welds based on the taguchi design method," Advances in Materials Science and Engineering, vol. 2018, Article ID 7950607, 7 pages, 2018.

[3] Q. Meng, P. La, L. Yao, P. Zhang, Y. Wei, and X. Guo, "Effect of $\mathrm{Al}$ on microstructure and properties of hot-rolled 2205 dual stainless steel," Advances in Materials Science and Engineering, vol. 2016, Article ID 7518067, 8 pages, 2016.

[4] Z.-g. Song, H. Feng, and S.-m. Hu, "Development of Chinese duplex stainless steel in recent years," Journal of Iron and Steel Research International, vol. 24, no. 2, pp. 121-130, 2017.

[5] Z. Y. Liu, C. F. Dong, X. G. Li, Q. Zhi, and Y. F. Cheng, "Stress corrosion cracking of 2205 duplex stainless steel in $\mathrm{H}_{2} \mathrm{~S}_{-}-\mathrm{CO}_{2}$ environment," Journal of Materials Science, vol. 44, no. 16, pp. 4228-4234, 2009.

[6] R. N. Gun, Duplex Stainless Steels, Vol. 1, Abington Publishing, Cambridge, UK, 1994.

[7] L.-F. Li, Z.-H. Jiang, and Y. Riquier, "High-temperature oxidation of duplex stainless steels in air and mixed gas of air and $\mathrm{CH}_{4}$," Corrosion Science, vol. 47, no. 1, pp. 57-68, 2005.

[8] J. G. Peng, M. C. Li, S. Z. Luo et al., "Oxidation characteristics of duplex stainless steel 2205 in simulated combustion atmosphere," Materials Research Innovation, vol. 19, no. suppl 5, pp. 245-249, 2015.

[9] J. G. Peng and M. C. Li, "High temperature oxidation behaviour of DSS 2205 in humid air," Advanced Materials Research, vol. 900, pp. 673-676, 2014.

[10] N. Ipek, B. Holm, R. Pettersson, G. Runnsjö, and M. Karlsson, "Electrolytic pickling of duplex stainless steel," Materials and Corrosion, vol. 56, no. 8, pp. 521-532, 2005.

[11] J. G. Peng, S. Z. Luo, and W. B. Dong, "Study on the simulated pickling of 443NT medium chrome ferritic stainless steel," Baosteel Technical Research, vol. 4, no. 1, pp. pp50-52, 2010.

[12] L.-F. Li, M. Daerden, P. Caenen, and J.-P. Celis, "Electrochemical behavior of hot-rolled 304 stainless steel during chemical pickling in HCl-based electrolytes," Journal of The Electrochemical Society, vol. 153, no. 5, pp. B145-B150, 2006.

[13] J. Hildén, J. Virtanen, O. Forsén, and J. Aromaa, "Electrolytic pickling of stainless steel studied by electrochemical polarisation and DC resistance measurements combined with surface analysis," Electrochimica Acta, vol. 46, no. 24-25, pp. 3859-3866, 2001.

[14] L.-F. Li, P. Caenen, and M.-F. Jiang, "Electrolytic pickling of the oxide layer on hot-rolled 304 stainless steel in sodium sulphate," Corrosion Science, vol. 50, no. 10, pp. 2824-2830, 2008.

[15] W. G. Chen, Y. Q. Chen, and H. L. Pang, "Study of $\mathrm{Na}_{2} \mathrm{SO}_{4}$ electrolytic pickling process on 304 stainless steel," China Metallurgy, vol. 19, no. 1, pp. 16-23, 2009.

[16] L.-F. Li, P. Caenen, and J.-P. Celis, "Chemical pickling of 304 stainless steel in fluoride- and sulfate-containing acidic electrolytes," Journal of The Electrochemical Society, vol. 152, no. 9, pp. B352-B357, 2005.

[17] C. A. Huang and C. C. Hsu, "The electrochemical polishing behaviour of duplex stainless steel (SAF 2205) in phosphoric-sulfuric mixed acids," International Journal of Advance Manufacture Technology, vol. 34, no. 9-10, pp. 904-910, 2007.

[18] L.-F. Li, P. Caenen, M. Daerden et al., "Mechanism of single and multiple step pickling of 304 stainless steel in acid electrolytes," Corrosion Science, vol. 47, no. 5, pp. 1307-1324, 2005.

[19] B. S. Covino, J. V. Scalera, T. J. Driscoll, and J. P. Carter, "Dissolution behavior of 304 stainless steel in $\mathrm{HNO}_{3} / \mathrm{HF}$ mixtures," Metallurgical Transactions A, vol. 17, no. 1, pp. 137-149, 1986.

[20] N. Ipek, N. Lior, M. Vynnycky, and F. H. Bark, "Numerical and experimental study of the effect of gas evolution in electrolytic pickling," Journal of Applied Electrochemistry, vol. 36, no. 12, pp. 1367-1379, 2006.

[21] M. Abdallah, "Guar gum as corrosion inhibitor for carbon steel in sulfuric acid solutions," Portugaliae Electrochimica Acta, vol. 22, no. 2, pp. 161-175, 2004.

[22] C. A. Huang, J. H. Chang, W. J. Zhao et al., "Examination of the electropolishing behaviour of 73 brass in a $70 \% \mathrm{H}_{3} \mathrm{PO}_{4}$ solution using a rotating disc electrode," Materials Chemistry and Physics, vol. 146, no. 3, pp. 230-239, 2014.

[23] Q. Xie, P.-y. Shi, C.-j. Liu, M.-f. Jiang et al., "Effects of different oxidants on $\mathrm{HCl}$-based pickling process of 430 stainless steel," Journal of Iron and Steel Research International, vol. 23, no. 8, pp. 778-783, 2016.

[24] W. H. Hao, L. Y. Qin, and D. L. Liu, "The effect of hydrochloric acid concentration on pickling of duplex stainless steel," Corrosion Protection, vol. 33, no. suppl 2, pp. 69-71, 2012.

[25] H. Y. Li and A. C. Zhao, "Pickling behaviour of duplex stainless steel 2205 in hydrochloric acid solution," Advances in Materials Science and Engineering, vol. 2018, Article ID 9754528, 6 pages, 2018.

[26] C. J. Brown, "Process and apparatus for recovery of peroxide containing pickling solutions," International Patent, PCT/ CA02/01598, 2002.

[27] R. Jiang, G. Zou, W. Shi, Y. Liang, and S. Xiang, "Corrosion behavior of plasma-nitrided 904L austenitic stainless steel in hydrofluoric acid," Journal of Materials Engineering and Performance, vol. 28, no. 3, pp. 1863-1872, 2019.

[28] Č. Donik, A. Kocijan, J. T. Grant, M. Jenko, A. Drenik, and B. Pihlar, "XPS study of duplex stainless steel oxidized by oxygen atoms," Corrosion Science, vol. 51, no. 4, pp. 827-832, 2009.

[29] Y. Xu, Q. Jin, J. Li, X. Xiao, X. Zhang, and L. Jiang, “Oxidation induced phase transformation of duplex stainless steel $25 \mathrm{Cr}$ $10 \mathrm{Mn}-2 \mathrm{Ni}-3 \mathrm{Mo}-0.8 \mathrm{~W}-0.8 \mathrm{Cu}-0.5 \mathrm{~N}$," Corrosion Science, vol. 55, pp. 233-237, 2012.

[30] ASM Handbook Committee, ASM Handbook Volume 5 Surface Engineering, ASM International, Cleveland, OH, USA, 2007.

[31] J. Eigeldinger and H. Vogt, "The bubble coverage of gasevolving electrodes in a flowing electrolyte," Electrochimica Acta, vol. 45, no. 27, pp. 4449-4456, 2000.

[32] M. Pourbaix, Atlas of Electrochemical Equilibria in Aqueous Solutions, Pergamon Press, Oxford, UK, 2nd edition, 1966.

[33] Z. G. Wang, H.-H. H. Wu, Q. Li et al., "Reversing interfacial catalysis of ambipolar $\mathrm{WSe}_{2}$ single crystal," Advanced Science, vol. 7, Article ID 1901382, pp. 1-9, 2019. 
[34] Z. Wang, Q. Li, H. Xu et al., "Controllable etching of $\mathrm{MoS}_{2}$ basal planes for enhanced hydrogen evolution through the formation of active edge sites," Nano Energy, vol. 49, pp. 634-643, 2018.

[35] M. C. Li, C. L. Zeng, S. Z. Luo, J. N. Shen, H. C. Lin, and C. N. Cao, "Electrochemical corrosion characteristics of type 316 stainless steel in simulated anode environment for PEMFC," Electrochimica Acta, vol. 48, no. 12, pp. 1735-1741, 2003. 